\title{
Penyuluhan Tentang Anemia pada Remaja
}

\author{
Sri Maharani \\ Prodi DIII Kebidanan STIKes Baiturrahim Jambi \\ Email:maharanibarus@gmail.com
}

\begin{abstract}
Anemia is a nutritional problemin the world which occurs not only in developing countries but also in developed countries. Low iron intake often occurs in people who consume foods that are less diverse, such as protein. Iron deficiency anemia is more common in young women than young men because young women experience menstruation every month and are in their infancy, thus requiring more iron intake. The problems faced by partners today include the lack of knowledge about adolescents about anemia, so it is considered necessary to provide counseling to provide knowledge to adolescents to prevent anemia in adolescents. Community Service Activities are carried out at SMP N 13 Jambi City. The time of implementation is in April 2018. The target is students of SMP N 13 Kota Jambi. Community service methods survey approach, lecture, discussion, demonstration / simulation. The results obtained are students able to understand about the prevention of anemia in adolescents. It is recommended that health workers, especially at the Puskesmas, give more counseling about anemia to young women before giving blood-added tablets, so that students get information about anemia and want to consume the added blood tablets.
\end{abstract}

Keywords: anemia, education, female adolescents

\begin{abstract}
Abstrak
Anemia merupakan masalah gizi yang banyak terdapat di seluruh dunia yang tidak hanya terjadi di negara berkembang tetapi juga di negara maju. Rendahnya asupan zat besi sering terjadi pada orang-orang yang mengkonsumsi bahan makanan yang kurang beragam, seperti protein. Anemia defisiensi zat besi lebih banyak terjadi pada remaja putri dibanding remaja putra dikarenakan remaja putri mengalami menstruasi setiap bulannya dan sedang dalam masa pertumbuhan, sehingga membutuhkan asupan zat besi yang lebih banyak. Permasalahan yang dihadapi mitra saat ini antara lain masih kurangnya pengetahuan remaja mengenai anemia maka dinilai perlu memberikan penyuluhan untuk memberikan pengetahuan kepada remaja untuk mencegah terjadinya anemia pada remaja. Kegiatan Pengabdian kepada masyarakat ini dilaksanakan di SMP N 13 Kota Jambi. Waktu pelsanaan pada bulan April 2018. Sasaran adalah siswi SMP N 13 Kota jambi. Metode pengabdian masyarakat pendekatan survey, ceramah, diskusi, demonstrasi/simulasi. Hasil yang diperoleh adalah siswi mampu memahami tentang pencegahan anemia pada remaja. Disarankan kepada petugas kesehatan khususnya di Puskesmas agar lebih memberikan penyuluhan tentang anemia pada remaja putri sebelum memberikan tablet tambah darah dilakukan secara berkal, sehingga siswi mendapatkan informasi tentang anemia dan mau mengkonsumsi tablet tambah darah yang diberikan.
\end{abstract}

Kata Kunci: anemia, pendidikan, remaja putri

\section{PENDAHULUAN}

Anemia merupakan masalah gizi yang banyak terdapat di seluruh dunia yang tidak hanya terjadi di negara berkembang tetapi juga di negara maju. Penderita anemia diperkirakan dua milyar dengan prevalensi terbanyak di wilayah Asia dan Afrika. World Health Organization (WHO) 
menyebutkan bahwa anemia merupakan 10 masalah kesehatan terbesar di abad modern ini, dimana kelompok yang berisiko tinggi anemia adalah wanita usia subur, ibu hamil, anak usia sekolah, dan remaja.

Anemia adalah keadaan dengan kadar hemoglobin, hematokrit dan sel darah merah yang lebih rendah dari nilai normal, yaitu hemoglobin $<12 \mathrm{~g} / \mathrm{dl}$ untuk remaja. Anemia menyebabkan darah tidak cukup mengikat dan mengangkut oksigen dari paru-paru ke seluruh tubuh. Bila oksigen yang diperlukan tidak cukup, maka akan berakibat pada sulitnya berkonsentrasi sehingga prestasi belajar menurun. Kemudian daya tahan fisik rendah sehingga mudah lelah, aktivitas fisik menurun dan mudah sakit karena daya tahan tubuh rendah, akibatnya jarang masuk sekolah atau bekerja.

Faktor utama penyebab anemia adalah asupan zat besi yang kurang. Rendahnya supan zat besi sering terjadi pada orang-orang yang mengkonsumsi bahan makanan yang kurang beragam, seperti protein. Kurangnya asupan protein akan mengakibatkan transportasi zat besi terlambat, sehingga akan terajadi defisiensi zat besi. Disamping itu, makanan yang tinggi protein teruma berasal dari daging, ikan dan unggas juga banyak mengandung protein. Anemia defisiensi zat besi lebih banyak terjadi pada remaja putri dibanding remaja putra. Hal ini dikarenakan remaja putri mengalami menstruasi setiap bulannya dan sedang dalam masa pertumbuhan, sehingga membutuhkan asupan zat besi yang lebih banyak.

\section{TARGET DAN LUARAN}

1. Target

Target dalam kegiatan pengabdian kepada masyarakat ini adalah siswi SMP N 13 Kota Jambi.

2. Luaran
Adapun luaran kegiatan pengabdan kepada masyarakat ini selain publikasi pada jurnal ilmiah yaitu:

a. Pemahaman siswi tentang anemia.

b. Kepatuhan remaja putri dalam mengkonsumsi tablet tambah darah.

c. Serta pemberian kesadaran remaja putri untuk mengkonsumsi makanan sehat.

\section{METODE PELAKSANAAN}

Kegiatan pengabdian kepada masyarakat dilaksanakan pada bulan April 2018 dengan sasaran kegiatan adalah siswi SMP N 13 Kota Jambi dengan jumlah 50 orang.

Tahapan kegiatan Pengabdian kepada kepada masyarakat meliputi:

Persiapan

1. Sosialisasi: pertemuan dengan pihak sekolah, kepala sekolah, guru BK dan petugas kesehatan di Puskesmas.

2. Mengidentifikasi masalah.

3. Perumusan solusi : Menyampaikan rencana kegiatan kepada pihak sekolah.

Pelaksanaan

1. Melakukan pretest (menggali pemahaman siswi tentang anemia)

2. Memberikan pendidikan kesehatan tentang anemia pada remaja putri (pengertian, macam-macam, gejala, pencegahan dan pengobatan).

3. Monitoring dan Evaluasi

\section{HASIL DAN PEMBAHASAN}

Kegiatan penyuluhan ini bertujuan agar siswi memahami tentang pentingnya pencegahan anemia. Pada pengabdian masyarakat ini dilakukan pendidikan kesehatan kepada remaja putri mengenai anemia. Kegiatan penyuluhan berlangsung kurang lebih 30 menit dan terlaksana dengan tertib dan lancar serta mendapat antusia yang baik dari peserta, maupun pihak sekolah. Kegiatannya adalah melakukan pendidikan kesehatan berupa penyuluhan tentang anemia pada remaja 
putri meliputi Definisi, Gejala-gejala, Pengobatan dan Pencegahan. Siswi cukup memahami dan sangat antusias dalam kegiatan ini, terbukti beberapa siswi bertanya khususnya tentang upaya pencegahan anemia.

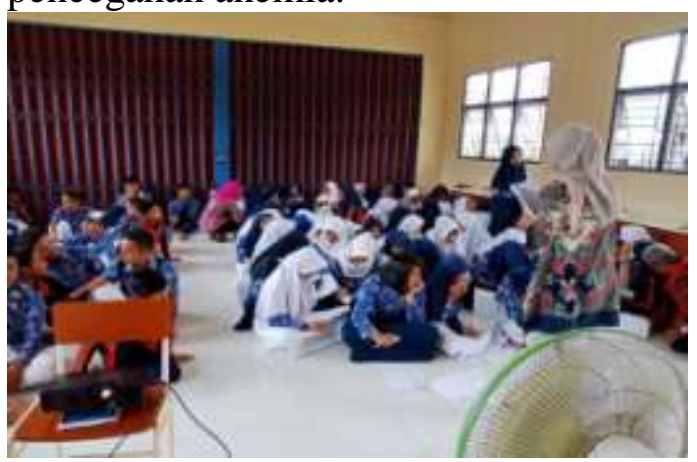

Gambar 1. Penyuluhan kesehatan

Gejala anemia antara lain muka pucat, kurang bertenaga, mudah mengantuk, sakit kepala dalam keadaan yang lebih parah bisa mengakibatkan peningkatan denyut jantung, nafas terengah-engah dan pingsan.

Pada pelaksanaan tindakan lebih difokuskan pada tindakan farmakologis dan nonfarmakologis, fakmakologis yaitu dengn pemberian tablet tambah darah, nonfarmakologis yaitu dengan mengkonsumsi makanan yang sehat dengan mencukupi nilai gizi sesuai kebutuhan remaja putri serta mengurangi konsumsi makanan cepat saji. Melakukan olahraga rutin seperti jogging, bersepeda atau berenang.

Pada akhir evaluasi dilakukan sesi tanya jawab untuk mengetahui sejauhmana pemahaman siswi tentang anemia.

\section{KESIMPULAN DAN SARAN}

1. Kesimpulan

Pelaksanaan pengabdian kepada mayarakat khususnya siswi SMP N 13 Kota Jambi yang dilakukan oleh dosen Sekolah Tinggi Ilmu Kesehatan Baiturahim Jambi berjalan dengan baik. Siswi yang hadir antusias dalam membaca power point yang ditampilkan dan bertanya apa yang mereka belum mengerti. Kegiatan ini memberikan pengalaman yang baik kepada para siswi untuk mencegah terjadinya anemia.

2. Saran

Agar pihak sekolah lebih sering mengadakan kegiatan yang memberikan pengetahuan bagi siswi dengan bekerjasama dengan pihak puskesmas sehingga dapat meningkatkan pengetahuan siswi tentang anemia pada remaja putri.

\section{UCAPAN TERIMAKASIH}

Ucapan terimakasih kami sampaikan kepada Sekolah Tinggi Ilmu Kesehatan Baiturrahim Jambi yang telah memfasilitasi kegiatan ini, dan tak lupa kepada kepala puskesmas dan kepala sekolah terkait serta semua pihak yang telah membantu kegiatan kepada masyarakat ini.

\section{DAFTAR PUSTAKA}

Almatsier, S. (2009). Prinsip Dasar Ilmu Gizi. Jakarta: Gramedia

Amudha, M. (2016). Prevalence of anemia among adolescent girls: A cross sectional exploratory study. International Journal of Applied Research 2016; 2(3): 630632.

Arumsari, E. (2008). Faktor Risiko Anemia Pada Remaja Putri Peserta Program Pencegahan Dan Penanggulangan Anemia Gizi Besi (PPAGB) Di Kota Bekasi. Program Studi Gizi Masyarakat dan Sumber Daya Keluarga Fakultas Pertanian Institut Pertanian Bogor.

Fauziah, D., Nurlina, \& Korneliani, K. (2012). Hubungan Antara Pola Menstruasi dan Konsumsi Zat Besi Dengan Kejadian Anemia Pada Remaja Putri Di SMA Informatika Ciamis. Program Studi Epidemiologi Dan Penyakit Tropik Fakultas Ilmu Kesehatan Universitas Siliwangi Tasikmalaya. 